Elements of Surprise 



\title{
Elements of Surprise
}

\author{
OUR MENTAL LIMITS
}

AND THE SATISFACTIONS

OF PLOT

VERA TOBIN

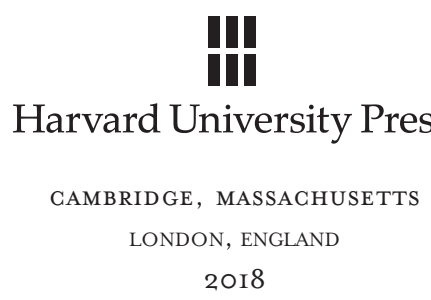


Copyright (C) 2018 by the President and Fellows of Harvard College

All rights reserved

Printed in the United States of America

First printing

Library of Congress Cataloging-in-Publication Data

Names: Tobin, Vera, 1975- author.

Title: Elements of surprise : our mental limits and the satisfactions

$$
\text { of plot / Vera Tobin. }
$$

Description: Cambridge, Massachusetts : Harvard University Press, 20r8. |

Includes bibliographical references and index.

Identifiers: LCCN 2017042678 | ISBN 9780674980204 (hardcover : alk. paper)

Subjects: LCSH: Plots (Drama, novel, etc.) | Surprise in literature. |

Literary anatomies. | Narration (Rhetoric) | Cognition.

Classification: LCC PN3378 .T53 20I8 | DDC 808.3/94-dc23

LC record available at https://lccn.loc.gov/2017042678

Cover design: Graciela Galup

Cover art: John Tenniel

Background: Getty royalty-free 
To Jane and Steve 
